\title{
A SKELETON OF THE DODO RAPHUS CUCULLATUS (L.) NEW TO ORNITHOLOGY
}

\author{
by \\ TIM G. BROM \& TINEKE G. PRINS \\ Institute of Taxonomic Zoology (Zoölogisch Museum), University of Amsterdam, \\ P.O. Box 4766, 1009 AT Amsterdam, The Netherlands
}

\begin{abstract}
A Dodo skeleton present in the Mineralogisch-Geologisch Museum at Delft, The Netherlands, is described. This specimen has hitherto not been described in the ornithological literature.
\end{abstract}

\section{RÉSUMÉ}

Un squelette de Dodo du Musée MinéralogiqueGéologique de Delft, Pays-Bas, est décrit. Cet exemplaire n'était pas encore décrit dans la littérature ornithologique.

The Dodo Raphus cucullatus (Linnaeus, 1758) from Mauritius was discovered in 1598 and became extinct in the 17 th century. Hundreds of pages have been devoted to this peculiar bird, but its systematic position and exact appearance still remain uncertain.

Since no single intact specimen has survived into post-Linnaean times, much of our current knowledge is based on paintings and sketches supposedly drawn from live birds. Several Dodos are known to have been shipped as curiosities to Europe, Java, India, and even Japan, but few remains of these are still preserved in European museums. The best known are the head and foot in the Oxford University Museum, the head in the Zoological Museum of Copenhagen, a foot in the British Museum (Natural History), and some skeletal remains in the Prague Museum of Natural History.

Our knowledge of the Dodo increased significantly with the discovery of bones at the Mare aux Songes on Mauritius (Clark, 1866; Vinson, 1967). A number of skeletons has been constructed, none of which, however, is that of a single bird. Some 10-15 composite and partial skeletons are present in museums and institu- tions throughout the world. To our knowledge, the skeletons in the Durban Museum of Natural History and the Cambridge University Museum of Zoology are the most complete (Newton \& Gadow, 1893; Chubb, 1919).

During our search for feather remains of the Dodo (Brom \& Prins, in press) our attention was drawn to a rather complete skeleton preserved in the Mineralogisch-Geologisch Museum of the University of Technology at Delft, The Netherlands (figs. $1 \& 2$ ). Although two authors (De Wit, 1940; Schuyf, 1970) have reported the existence of this Dodo skeleton, it has never been described in the ornithological literature nor mentioned in reference works (Lambrecht, 1933; Hachisuka, 1953; Lüttschwager, 1961). Furthermore, it was not listed in the recently compiled world inventory of avian skeletal material (Wood et al., 1982).

All that is known about the history of the Delft skeleton is that the remains from which it was reconstructed were excavated in Mauritius by an anonymous Frenchman around 1900, and that early in 1940 the skeleton was purchased from Maison Deyrolle in Paris* by the Curator of the Mineralogisch-Geologisch Museum, Prof. Dr. J. H. F. Umbgrove.

The skeleton consists of a number of original bones (listed in table I), augmented with casts

* During the preparation of this paper, Dr. R. Duguy kindly informed us that the Muséum d'Histoire Naturelle at la Rochelle, France, has a nearly complete skeleton of the Dodo in its collection. Likewise, this specimen was purchased from Maison Deyrolle (in 1934) and was mentioned in C. Jouanin, 1966: Oiseaux éteints ou en voie d'extinction du Musée de la Rochelle. Annls. Soc. Sci. Nat. Charente-Maritime, 4 (6): 1-7. 


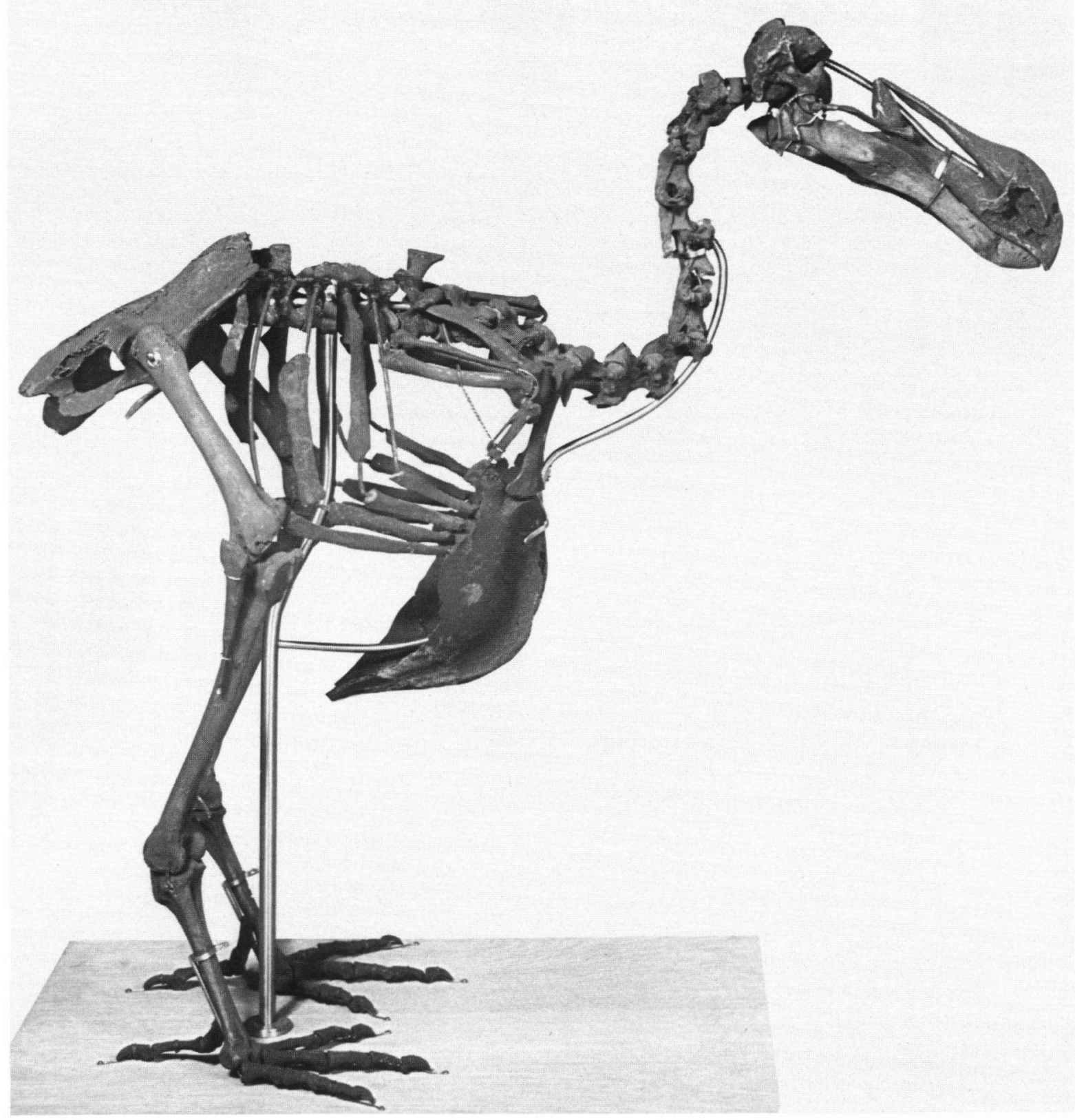

Fig. 1. Lateral view of the Dodo skeleton in the Mineralogisch-Geologisch Museum at Delft.

from parts of the skeleton in the Mauritius Institute at Port Louis (De Wit, 1940). From the differences in size between the left and right leg it is concluded that this skeleton has been reconstructed from the remains of more than one bird. The measurements presented in table I are similar to those taken from other skeletons
(Strickland \& Melville, 1848; Lüttschwager, 1961).

Since 1866 the osteology of the Dodo has been subject of much research (cf. Owen \& Broderip, 1866), which has led to the opinion, nowadays generally accepted, that it shares most similarities with the pigeons. However, 
TABLE I

Original parts of the Dodo skeleton at Delft

Skull: dentale, angulare, and supra-angulare (total length of lower jaw: left $178 \mathrm{~mm}$, right $182 \mathrm{~mm}$ )

Vertebrae cervicales nrs. 3-13

Vertebrae thoracales nrs. 1-3

Vertebrae sacrales nrs. 1-15

Sternum (max. width $110 \mathrm{~mm}$, max. length $166 \mathrm{~mm}$, width of crista sterni $10.4 \mathrm{~mm}$ )

Left scapula (98 mm, but damaged)

Ischium

Ilium (max. width $124 \mathrm{~mm}$ )

Pubis (badly damaged)

Left femur (min. length $136 \mathrm{~mm}$, max. length $149 \mathrm{~mm}$, min. width $16.4 \mathrm{~mm}$ )

Right femur (min. length $133 \mathrm{~mm}$, max. length $144 \mathrm{~mm}$, min. width $15.7 \mathrm{~mm}$ )

Left tibiotarsus (max. length $199 \mathrm{~mm}$, min. width 14.0 $\mathrm{mm}$ )

Right tibiotarsus (max. length $208 \mathrm{~mm}$, min. width 13.7 $\mathrm{mm}$ )

Left tarsometatarsus (max. length $124 \mathrm{~mm}$ )

Right tarsometatarsus (max. length $130 \mathrm{~mm}$ ) neither the traditional osteological studies nor our recent microscopic investigation of feather remains (Brom \& Prins, in press) have yielded synapomorphies for the Dodo and the Columbidae. Thus, alternative hypotheses on the affinities of this intriguing bird (Lüttschwager, 1961) have not been falsified as yet. If the phylogenetic relationships of this bird are ever to be elucidated, we expect the answer to come from osteological studies sufficiently comparative to support phylogenetic arguments. It is therefore of great importance that all remains of the Dodo that still exist be documented in the ornithological literature.

\section{ACKNOWLEDGEMENTS}

We thank Ir. Chr. Maugenest, Curator of the Mineralogisch-Geologisch Museum, Delft, for his kind permission to study the skeleton, Dr. P. J. H. van Bree for informing us of the existence of a Dodo skeleton in The Netherlands, and Louis A. van der Laan who made the photographs.

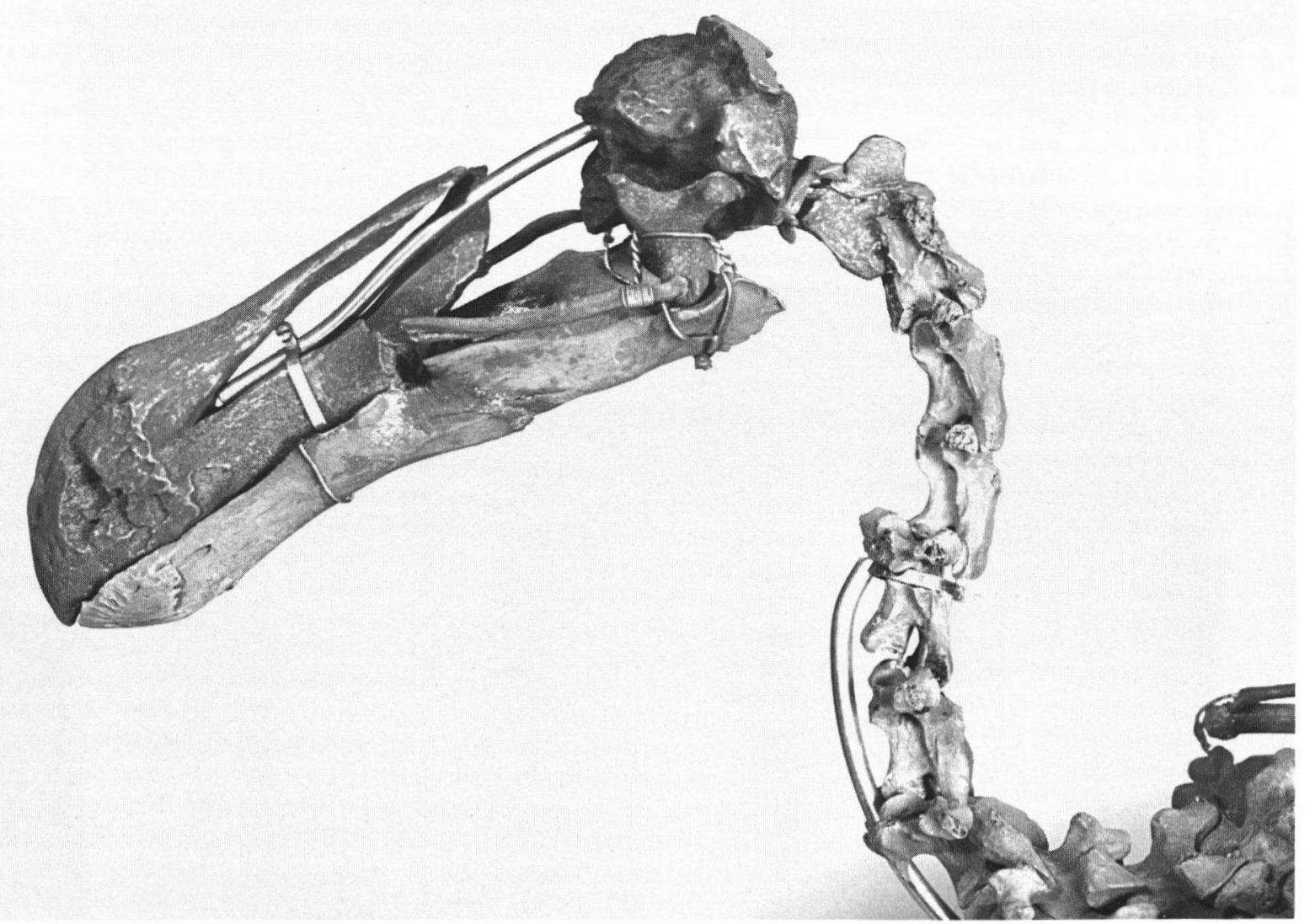

Fig. 2. Detail of the head and neck region of the Dodo skeleton in the Mineralogisch-Geologisch Museum at Delft. 


\section{REFERENCES}

Brom, T. G. * T. G. Prins, in press. Microscopic investigation of feather remains from the head of the Oxford Dodo, Raphus cucullatus (L.) J. Zool., Lond.

Chubb, E. C., 1919. A skeleton of the Dodo (Didus ineptus). Ann. Durban Mus., 2 (3): 97-99, pl. XVII.

Clark, G., 1866. Account of the late discovery of Dodo's remains in the island of Mauritius. Ibis, 1866: 141-146.

Hachisuka, M., 1953. The Dodo and kindred birds or the extinct birds of the Mascarene Islands: i-xvi, 1250, pls. I-XXII (H. F. \& G. Witherby, London).

Lambrecht, K., 1933. Handbuch der Palaeornithologie: i-ix, 1-1024, pls. I-IV (Borntraeger, Berlin).

Lüttschwager, J., 1961. Die Drontevögel. Die neue Brehm-Bücherei, 276: 1-60 (A. Ziemsen, Wittenberg Lutherstadt).

Newton, E. H. Gadow, 1893. On additional bones of the Dodo and other extinct birds of Mauritius obtained by Mr. Théodore Sauzier. Trans. zool. Soc. Lond., 13 (VII, 1): 281-302, pls. XXXIIIXXXVII.
OWen, R. \& W. J. Broderip, 1866. Memoir on the Dodo (Didus ineptus, Linn.): 1-56, pls. I-XII (Taylor * Francis, London).

SchuYf, P., 1970. Een skelet van de in historische tijd uitgestorven vogel dodo (Raphus cucullatus Linné) van Mauritius in het Mineralogisch-Geologisch Museum te Delft. Grondboor en Hamer, 1970 (1): 4-14.

Strickland, H. E. A. G. Melville, 1848. The Dodo and its kindred; or the history, affinities, and osteology of the Dodo, Solitaire, and other extinct birds of the islands Mauritius, Rodriguez, and Bourbon: [i-ix], 1-141, 18 pls. (Reeve, Benham \& Reeve, London).

Vinson, J., 1967. Le centenaire de la découverte à l'île Maurice des ossements du Dronte ou Dodo, Raphus cucullatus Linné. Proc. roy. Soc. Arts Sci. Mauritius, 3 (1): 1-5.

WIt, R. DE, 1940. Een skelet van de Dodo te Delft. Geologie en Mijnbouw, 2 (9): 197-200.

Wood, D. S., R. L. Zusi \& M. A. Jenkinson, 1982. World inventory of avian skeletal specimens: 1-224 (American Ornithologist's Union \& Oklahoma Biological Survey, Norman, Oklahoma). 